\title{
FKBP5 expression in human adipose tissue: potential role in glucose and lipid metabolism, adipogenesis and type 2 diabetes
}

\author{
Cherno O. Sidibeh $^{1} \cdot$ Maria J. Pereira ${ }^{1} \cdot$ Xesus M. Abalo $^{1} \cdot$ Gretha J. Boersma $^{1} \cdot$ Stanko Skrtic $^{2,3} \cdot$ Per Lundkvist $^{1}$. \\ Petros Katsogiannos ${ }^{1} \cdot$ Felix Hausch $^{4} \cdot$ Casimiro Castillejo-López $^{1} \cdot$ Jan W. Eriksson $^{1}$
}

Received: 16 March 2018 / Accepted: 2 July 2018 / Published online: 21 July 2018

(c) The Author(s) 2018

\begin{abstract}
Purpose Here, we explore the involvement of FKBP51 in glucocorticoid-induced insulin resistance (IR) in human subcutaneous adipose tissue (SAT), including its potential role in type 2 diabetes (T2D). Moreover, we assess the metabolic effects of reducing the activity of FKBP51 using the specific inhibitor SAFit1.

Methods Human SAT was obtained by needle biopsies of the lower abdominal region. FKBP5 gene expression was assessed in fresh SAT explants from a cohort of 20 T2D subjects group-wise matched by gender, age and BMI to 20 nondiabetic subjects. In addition, human SAT was obtained from non-diabetic volunteers (20F/9M). SAT was incubated for $24 \mathrm{~h}$ with or without the synthetic glucocorticoid dexamethasone and SAFit1. Incubated SAT was used to measure the glucose uptake rate in isolated adipocytes.

Results FKBP5 gene expression levels in SAT positively correlated with several indices of IR as well as glucose area under the curve during oral glucose tolerance test $(r=0.33, p<0.05)$. FKBP5 gene expression levels tended to be higher in T2D subjects compared to non-diabetic subjects $(p=0.088)$. Moreover, FKBP5 gene expression levels were found to inversely correlate with lipolytic, lipogenic and adipogenic genes. SAFit1 partly prevented the inhibitory effects of dexamethasone on glucose uptake.

Conclusions FKBP5 gene expression in human SAT tends to be increased in T2D subjects and is related to elevated glucose levels. Moreover, FKBP5 gene expression is inversely associated with the expression of lipolytic, lipogenic and adipogenic genes. SAFit1 can partly prevent glucose uptake impairment by glucocorticoids, suggesting that FKBP51 might be a key factor in glucocorticoid-induced IR.
\end{abstract}

Keywords Type 2 diabetes $\cdot$ Glucocorticoids $\cdot$ Insulin resistance $\cdot$ Adipose tissue $\cdot$ FKBP51 $\cdot$ SAFit1

\section{Abbreviations \\ AUC area under the curve \\ DAPI diamidino-2-phenylindole}

Electronic supplementary material The online version of this article (https://doi.org/10.1007/s12020-018-1674-5) contains supplementary material, which is available to authorized users.

\footnotetext{
Jan W. Eriksson

jan.eriksson@medsci.uu.se

1 Department of Medical Sciences, Uppsala University, Uppsala, Sweden

2 AstraZeneca R\&D, Mölndal, Sweden

3 Institute of Medicine, Sahlgrenska Academy, University of Gothenburg, Gothenburg, Sweden

4 Institute of Organic Chemistry and Biochemistry, Technical University Darmstadt, Darmstadt, Germany
}

$\begin{array}{ll}\text { DM } & \text { differentiation medium } \\ \text { DMEM } & \text { Dulbecco's modified Eagle medium } \\ \text { FBS } & \text { fetal bovine serum } \\ \text { FK } & \text { FKBP-type } \\ \text { FKBP51 } & \text { FK506 binding protein 51 } \\ \text { FKBP52 } & \text { FK506 binding protein 52 } \\ \text { GR } & \text { glucocorticoid receptor } \\ \text { HPA-axis } & \text { hypothalamic-pituitary-adrenal axis } \\ \text { Hsp90 } & \text { heat shock protein 90 } \\ \text { Matsuda } & \text { Matsuda insulin sensitivity index } \\ \text { OGTT } & \text { oral glucose tolerance test } \\ \text { PEST } & \text { penicillin-streptomycin } \\ \text { PKB/Akt } & \text { protein kinase B } \\ \text { SAT } & \text { subcutaneous adipose tissue } \\ \text { SVF } & \text { stromal vascular fraction } \\ \text { TPR } & \text { tetratricopeptide repeat } \\ \text { T2D } & \text { type 2 diabetes }\end{array}$




\section{Introduction}

Type 2 diabetes (T2D) is a metabolic condition with ever increasing global prevalence. The World Health Organization reported that in 2014, the overall prevalence of diabetes was $8.5 \%$ among adults [1], increasing from $4.7 \%$ since 1980. Obesity is strongly associated with a state of insulin resistance [2-4] where tissues and organs such as adipose tissue, skeletal muscle and liver inadequately respond to insulin [5]. Insulin resistance, in combination with beta cell dysfunction, is usually critical for the development and progression of T2D [6, 7]. It is therefore of strong clinical relevance to elucidate the underlying causes and mechanisms involved in obesity and insulin resistance.

Steroid hormones, such as glucocorticoids, can be used as tools to achieve a better understanding of the development of obesity and insulin resistance. Glucocorticoids have found their way to frequent clinical use because of their anti-inflammatory and immunosuppressive properties [8,9]. However, high exogenous or endogenous levels are linked to several adverse metabolic effects including increased obesity, insulin resistance and onset of diabetes similar to T2D [10, 11]. We recently assessed glucocorticoid effects on gene expression in human adipose tissue in a microarraybased approach [12]. We found that FKBP5, the gene that codes for FK506 binding protein 51 (FKBP51), was highly upregulated by the synthetic glucocorticoid dexamethasone in human subcutaneous and omental adipose tissue [12]. FKBP5 gene expression levels were also found to be associated with markers of insulin resistance [12].

FKBP51 is a protein that has mostly been studied in the field of psychiatric disorders including anxiety and depression [13, 14]. This is likely due to the key role of FKBP51 in the hypothalamic-pituitary-adrenal axis (HPAaxis) [15]. The HPA-axis has a feedback control system that regulates the release of glucocorticoids, e.g. in response to stress $[15,16]$. However, glucocorticoids have systemic metabolic effects beyond the central nervous system, on organs such as the pancreas, skeletal muscle and adipose tissue [17]. In addition, FKBP51 has increasingly emerged as a player in metabolic regulation [18]. This includes a recent report where the rs 1360780 polymorphism of the FKBP5 gene has been associated with reduced weight loss following bariatric surgery [19]. Furthermore, FKBP51 has been shown to regulate Akt/protein kinase $\mathrm{B}$ (PKB) activity [20], thus indicating an association between FKBP51 and insulin resistance. Studies in FKBP5 knockout mice have also proposed FKBP51 as a link between chronic stress and obesity. Mice lacking the FKBP5 gene have reduced bodyweight compared to wildtype mice and are resistant to diet-induced obesity $[21,22]$. Furthermore, FKBP51 has been reported to play a role in adipogenesis in mousederived cells $[23,24]$. The role of FKBP51 in systemic metabolism is further supported by its higher expression levels in metabolically active tissues such as skeletal muscle and adipose tissue in comparison to other tissues [18, 25].

FKBP51 resides in the cellular cytosol where its principal function is to regulate the glucocorticoid response through interaction with the glucocorticoid receptor (GR) as part of its downstream signalling. The GR, also located in the cytosol, forms a complex made up of multiple co-factors and chaperones. These include heat shock protein 90 (Hsp90), p23, FKBP51 and FK506 binding protein 52 (FKBP52) [26]. FKBP51 and FKPB52 compete for the binding to the GR-associated HSP90. An FKBP51associated GR-complex has a low affinity for glucocorticoids, whereas an FKBP52-associated GR-complex has a high affinity for glucocorticoids [27]. When a glucocorticoid diffuses through the cell membrane it binds to the FKBP52-associated GR-complex. This facilitates the translocation of the entire complex into the nucleus where it binds to specific DNA response elements triggering the activation or suppression of gene transcription. One of the principal genes that is upregulated in this chain of events is the FKBP51-coding gene. FKBP51 thereby regulates its own expression in what is referred to as an ultra-short negative feedback loop [26-29].

To date, there are very few studies of FKBP51 in metabolically active tissues. Here, we want to further expand upon our previous findings where we established a relationship between FKBP51, glucocorticoids, insulin resistance and the impairment of insulin-stimulated glucose uptake in human adipose tissue [12]. Moreover, we want to explore the role of FKBP51 in T2D with respect to adipose metabolism and function. This includes elucidating its potential role in adipogenesis [23] and providing insight into what role, if any, FKBP51 may have in lipid metabolism.

\section{Materials and methods}

\section{Adipose tissue donors}

\section{Cohort 1}

Human subcutaneous adipose tissue (SAT) was obtained from a cohort of $20 \mathrm{~T} 2 \mathrm{D}$ subjects and 20 non-diabetic subjects, matched by gender $(10 \mathrm{~F} / 10 \mathrm{M})$, age $(58 \pm 9$ vs $58 \pm 11$ years, respectively) and BMI $(30.7 \pm 4.9$ vs $30.8 \pm$ $4.6 \mathrm{~kg} / \mathrm{m}^{2}$, respectively). Fasting blood samples, oral glucose tolerance test (OGTT) and SAT needle biopsies were performed as previously described $[12,30]$. SAT was acquired by needle aspiration of the lower abdominal region after local dermal anaesthesia with lidocaine (Xylocain; AstraZeneca, Sweden). Part of the adipose tissue was snap 
Table 1 Clinical characteristics of study participants

\begin{tabular}{|c|c|c|c|c|c|c|}
\hline & Cohort 1 & & & & Cohort 2 & \\
\hline & ND & & $\mathrm{T} 2 \mathrm{D}$ & & & \\
\hline & Average & Range & Average & Range & Average & Range \\
\hline$N$ & $20(10 \mathrm{M}, 10 \mathrm{~F})$ & & $20(10 \mathrm{M}, 10 \mathrm{~F})$ & & $29(20 \mathrm{~F}, 9 \mathrm{M})$ & \\
\hline Age, years & 58 & $34-72$ & 58 & $41-71$ & 46 & $18-72$ \\
\hline BMI $\left(\mathrm{kg} / \mathrm{m}^{2}\right)$ & 30.8 & $22.7-38.4$ & 30.7 & $22.5-39.9$ & 27.4 & $22.7-47.2$ \\
\hline WHR & 0.96 & $0.84-1.09$ & 0.99 & $0.90-1.08$ & 0.87 & $0.74-1.00$ \\
\hline Sc adipocyte diameter $(\mu \mathrm{m})$ & 109.6 & $91.4-124.7$ & 106.4 & $82.6-124.6$ & 102.1 & $73.2-126.7$ \\
\hline P-glucose (mmol/L) & 6.0 & $4.9-7.3$ & 8.2 & $6.1-11.5$ & 5.7 & $4.6-6.7$ \\
\hline Serum insulin $(\mathrm{mU} / \mathrm{L})$ & 11.5 & $4.1-26.0$ & 15.5 & $4.1-31.0$ & 8.3 & $2.4-26.0$ \\
\hline HOMA-IR & 3.08 & $1.17-7.33$ & 5.27 & $1.25-10.83$ & 2.15 & $0.57-7.40$ \\
\hline $\mathrm{HbA}_{1 \mathrm{c}}, \mathrm{IFCC}(\mathrm{mmol} / \mathrm{mol})$ & 37.3 & $31.0-46.0$ & 48.8 & $37.0-73.0$ & 32.8 & $22.0-40.0$ \\
\hline $\mathrm{HbA}_{1 \mathrm{c}}(\%)$ & 5.6 & $5.0-6.4$ & 6.6 & $5.5-8.8$ & 5.2 & $4.2-6.6$ \\
\hline P-total cholesterol $(\mathrm{mmol} / \mathrm{L})$ & 5.7 & $4.4-8.4$ & 4.9 & $3.1-6.8$ & 5.0 & $3.0-7.2$ \\
\hline P-HDL-cholesterol $(\mathrm{mmol} / \mathrm{L})$ & 1.3 & $0.9-1.9$ & 1.2 & $0.8-1.8$ & 1.5 & $0.8-2.3$ \\
\hline P-LDL-cholesterol $(\mathrm{mmol} / \mathrm{L})$ & 3.6 & $1.9-6.0$ & 3.1 & $1.8-4.9$ & 3.0 & $1.0-5.2$ \\
\hline P-triglycerides $(\mathrm{mmol} / \mathrm{L})$ & 1.6 & $0.7-3.5$ & 1.6 & $0.6-2.6$ & 1.0 & $0.6-2.2$ \\
\hline
\end{tabular}

$N D$ non-diabetic, $B M I$ body mass index, WHR waist-hip ratio, $S c$ subcutaneous, HOMA-IR homoeostatic model assessment of insulin resistance, $H b A_{l c}$ glycated haemoglobin, $P$ plasma, $H D L$ high-density lipoprotein, $L D L$ low-density lipoprotein frozen in liquid nitrogen, stored at $-80{ }^{\circ} \mathrm{C}$ and used to assess gene expression levels of FKBP5, other glucocorticoid-regulated genes and genes involved in adipogenesis and glucose, lipid and energy metabolism. SAT and plasma were also used to measure fasting cortisone and cortisol levels. In addition, SAT was used to measure ex vivo glucose uptake and lipolysis in isolated adipocytes. All measurements were performed as previously described [30]. Clinical and biochemical characteristics of the subjects are shown in Table 1.

\section{Cohort 2}

For the second cohort, the same procedure was used to extract SAT, in this case from non-diabetic volunteers $(20 \mathrm{~F} /$ $9 \mathrm{M}, 18-72$ years, BMI $22.7-47.2 \mathrm{~kg} / \mathrm{m}^{2}$ ), and used to assess gene expression levels for FKBP5 and other genes known to be regulated by the GR-complex $(n=9)$. In addition, SAT was used to isolate preadipocytes to investigate the role of FKBP51 in adipogenesis $(n=3)$. SAT samples were also used to study the effects of dexamethasone treatment and SAFit1, an FKBP51-specific inhibitor [31], on glucose uptake in isolated primary adipocytes $(n=19)$. Due to limited amounts of SAT obtained from biopsies, not all experiments were performed on samples from every subject.

Fasting blood samples were collected for analysis of plasma glucose, insulin and lipids at the Department of Clinical Chemistry at Uppsala University Hospital. Subjects with type 1 diabetes and/or T2D, other endocrine disorders, cancer or other major illnesses, as well as ongoing medication with beta-adrenergic blockers, systemic glucocorticoids or immune-modulating therapies were excluded from the study. Clinical and biochemical characteristics of the subjects are shown in Table 1.

The study protocols were approved by the Regional Ethics Review in Uppsala (Dnr 2013/330 and Dnr 2013183/494). Written informed consent was obtained from all study participants.

\section{mRNA levels assessment}

mRNA expression levels of FKBP5, other glucocorticoidregulated genes and genes involved in adipogenesis and glucose, lipid and energy metabolism, in SAT from Cohort 1, were measured by RNAseq at Exiqon A/S, Vedbaek, Denmark, as previously described [30].

For real-time PCR assays, RNA was isolated from incubated SAT from Cohort 2 subjects or preadipocytes in culture using the RNeasy Lipid Tissue Mini Kit (Qiagen, Hilden, Germany) according to manufacturer's protocol. Purified RNA was quantified using a NanoDrop ND-1000 spectrophotometer (NanoDrop Technologies, Wilmington, DE, USA). This was followed by conversion of RNA to cDNA using a high-capacity cDNA reverse transcription kit (Applied Biosystems, Foster City, CA, USA) and relative quantification using TaqMan probes towards target genes. See Supplementary Materials and Methods for details on real-time PCR assay.

\section{Adipose tissue incubation and assessments}

The potency of glucocorticoids was assessed as their effects on $\beta$-adrenergic receptor expression (EC50 $4.8 \mathrm{nmol} / \mathrm{L}$ for dexamethasone $24 \mathrm{nmol} / \mathrm{L}$ for cortisol). In this context, 
dexamethasone has been shown to elicit $\sim 5$ times the potency of cortisol (EC50 $4.8 \mathrm{nmol} / \mathrm{L}$ for dexamethasone and $24 \mathrm{nmol} / \mathrm{L}$ for cortisol) [32]. Therefore a $0.3 \mu \mathrm{M}$ concentration of dexamethasone would correspond to a maximum physiological plasma level of cortisol under stress conditions of about 1-2 $\mu \mathrm{M}$ [33].

SAT obtained from Cohort 1 subjects was instantaneously used to isolate primary adipocytes by collagenase (Sigma-Aldrich, St. Louis, MO, USA) treatment. Following isolation, primary adipocytes were washed in glucose-free Krebs-Ringer-Hepes medium or Hank's medium 199 for glucose uptake or lipolysis assays, respectively. Medium was supplemented with $4 \%$ bovine serum albumin and $150 \mathrm{nM}$ adenosine. Following washing, glucose uptake and lipolysis assays were performed as previously described [12, 30]. See Supplementary Materials and Methods for additional details on the glucose uptake and lipolysis assays.

SAT from Cohort 2 was incubated in Dulbecco's modified Eagle medium (DMEM, Invitrogen; $6 \mathrm{mM}$ glucose, $10 \%$ fetal bovine serum (FBS), $1 \%$ penicillin-streptomycin (PEST)) with or without the glucocorticoid dexamethasone $(0.3 \mu \mathrm{M})$ and with or without an FKBP5-selective small molecule inhibitor SAFit1 [33] (100, 500, 2000 or $10,000 \mathrm{nM}$ concentrations) for $24 \mathrm{~h}(n=7-19)$. Furthermore, SAT was incubated in DMEM (6 mM glucose, with $10 \% \mathrm{FBS}, 1 \% \mathrm{PEST}$ ) for $24 \mathrm{~h}$ in $37^{\circ} \mathrm{C}, 5 \% \mathrm{CO}_{2}$ with or without SAFit1 alone $(500 \mathrm{nM}, n=4)$. This was to assess the dependency of the effects of SAFit1 on the presence of glucocorticoids. Incubated SAT was used to test the effects of dexamethasone and the FKBP51 inhibitor on subsequent adipocyte glucose uptake as previously described [12, 30]. See Supplementary Materials and Methods for additional details on the glucose uptake assays.

Furthermore, part of the SAT was incubated with or without dexamethasone $(0.3 \mu \mathrm{M})$ or dexamethasone together with SAFit1 for gene expression analyses (500 nM, $n$ $=9)$.

\section{Stromal vascular fraction assessment}

To assess the involvement of FKBP51 in human adipogenesis, the stromal vascular fraction (SVF), that contains preadipocytes, was isolated from human SAT. Fresh SAT from Cohort 2 was treated with collagenase (SigmaAldrich), to separate the SVF cells from the mature adipocytes, as previously described $[12,30]$. The SVF was then cultured in preadipocyte medium until reaching a confluency of $70-80 \%$. Cells were expanded until $\sim 1,000,000$ cells and transferred to 24-well plates at a density of 15,000 cells $/ \mathrm{cm}^{2}$. Upon reaching $100 \%$ confluence, cells were differentiated as previously described [34, 35]. Preadipocytes were maintained in differentiation medium for a total of 14 days. Samples for gene and protein expression were collected on days 0,7 and $14(n=5)$. In addition, Oil Red $\mathrm{O}$ staining and subsequent imaging of differentiating cells were performed on days 7 and 14 of differentiation ( $n$ $=3$ ). See Supplementary Materials and Methods for more details regarding preadipocyte differentiation.

\section{Imaging and quantification of adipocyte differentiation}

The lipids of the adipocytes undergoing ex-vivo differentiation were stained with Oil Red $\mathrm{O}$ solution on days 7 and 14 of differentiation. This was performed to quantify lipid accumulation and the rate of differentiation. See Supplementary Materials and Methods for details.

\section{Glucose uptake in adipocytes differentiated ex-vivo}

Glucose uptake was assessed in ex-vivo differentiated human adipocytes $(n=4)$. The effects of dexamethasone on the glucose uptake rates of differentiated adipocytes were also assessed. On day 14 of differentiation, adipocytes were deprived of glucocorticoids for $48 \mathrm{~h}$. On day 16, media was supplemented with $0.3 \mu \mathrm{M}$ of dexamethasone for $24 \mathrm{~h}$ and on day 17 , glucose uptake was performed as previously described [34, 36, 37]. In addition, samples for gene $(n=2)$ and protein $(n=4)$ expression were collected on day 17 .

\section{Western blot}

Protein lysates of cells in culture or homogenised adipose tissue were assessed using western blotting. In brief, blotting was performed by using equal amounts of protein for all samples $(10 \mu \mathrm{g})$ and with the use of primary antibody to FKBP51 (ab126715, Abcam, Cambridge, UK; diluted 1:1000). Horseradish peroxidase-linked anti-rabbit IgG antibody (7074S, CST, diluted 1:2000) was used as a secondary antibody.

\section{Statistical analysis}

All data are presented as mean \pm SEM, unless stated otherwise. All statistical analyses were performed using IBM SPSS Statistics software. The Shapiro-Wilk test of normality was used to determine the normal distribution of data sets.

SAT gene expression data from Cohort 1 was logtransformed. Pearson's bivariate correlation test was used to explore the associations between gene transcripts with respect to $F K B P 5$. Spearman's bivariate correlation test was used to assess correlations between FKBP5 gene expression and metabolic parameters in Cohort 1 . Significant variables were subsequently included in multivariate stepwise regression analyses. 
A

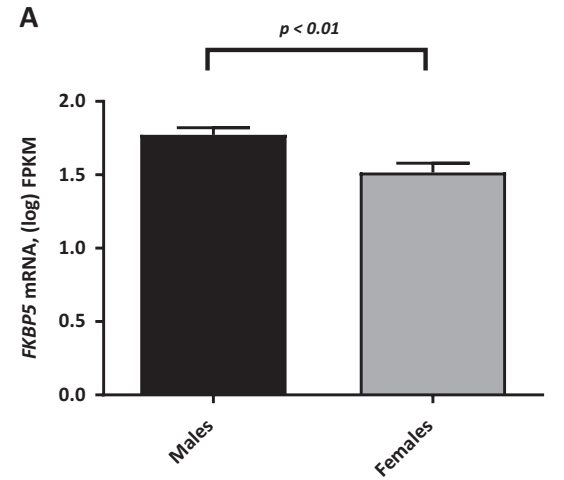

B

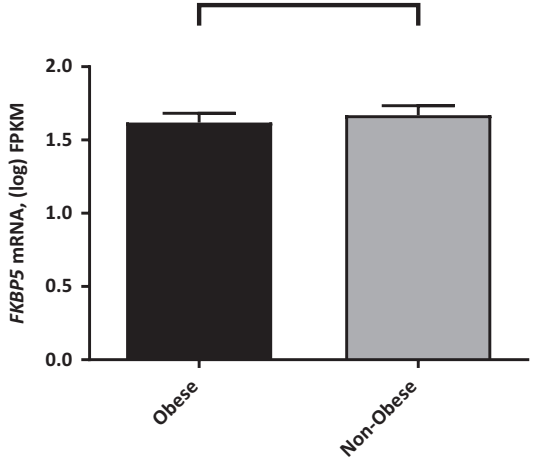

C

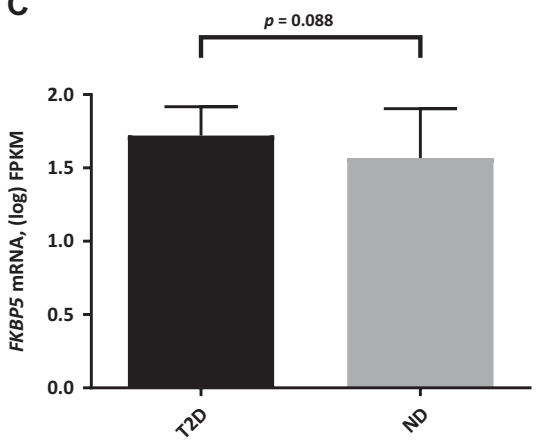

Fig. 1 FKBP5 gene expression is higher in SAT from male subjects compared to SAT from female subjects a. FKBP5 gene expression levels in SAT do not differ between non-obese and obese subjects $\mathbf{b}$.

Analyses of differences in gene and protein expression, differentiation rate and glucose uptake in Cohort 2 SAT and adipocytes differentiated ex vivo, were performed pairwise using the paired-samples $t$ test.

Spearman's bivariate correlation test was used to assess correlations of the percentage effects on glucose uptake by dexamethasone treatment vs dexamethasone and SAFit1 cotreatment in Cohort 2. A $p$-value $<0.05$ was considered statistically significant.

\section{Results}

\section{FKBP5 expression levels in SAT}

SAT from males in Cohort 1 had $\sim 16 \%$ higher gene expression levels of FKBP5 $(p<0.01)$ than females (Fig. 1a). There was also a tendency of higher FKBP5 gene expression in SAT from T2D subjects (by 10\%, $p=0.088$ ) compared to healthy subjects (Fig. 1c). No differences were found between non-obese and obese subjects (Fig. 1b).

\section{Association between FKBP5 gene expression levels in SAT and metabolic parameters}

FKBP5 gene expression levels positively correlated with markers of insulin resistance, including the glucose area under the curve (AUC) during OGTT $(r=0.33, p<0.05)$, fasting glucose $(r=0.47, p<0.01)$, Quantitative Insulin Sensitivity Check Index (QUICKI; $r=-0.33, \mathrm{p}<0.05$ ) and HOMA-IR $(r=0.34, p<0.05)$. FKBP5 gene expression also correlated negatively with OGTT-derived insulin sensitivity indices, Matsuda $(r=-0.34, p<0.05)$ and Gutt $(r$ $=-0.32, p<0.05)$. An association was also found between FKBP5 gene expression and systolic blood pressure (SBP) $(r=0.32, p<0.05)$. After inclusion of glucose AUC during OGTT, HOMA-IR, Matsuda index and SBP in a
There was a tendency of higher FKBP5 gene expression in SAT from T2D subjects compared to non-diabetic subjects c. $n=20$, each group. ND non-diabetic, NS not significant

Table 2 Association between FKBP5 gene expression in SAT and metabolic parameters in Cohort 1 subjects $(n=40)$

\begin{tabular}{|c|c|c|c|c|}
\hline \multirow[t]{3}{*}{ Metabolic parameters (Cohort 1) } & \multicolumn{4}{|c|}{ FKBP5 gene expression } \\
\hline & \multicolumn{2}{|c|}{$\begin{array}{l}\text { Bivariate } \\
\text { correlation }^{\text {a }}\end{array}$} & \multicolumn{2}{|c|}{$\begin{array}{l}\text { Multivariate } \\
\text { stepwise } \\
\text { regression }^{\mathrm{b}}\end{array}$} \\
\hline & $r$ & $p$ & $\operatorname{Std} \beta$ & $p$ \\
\hline AUC glucose & 0.33 & 0.039 & 0.32 & 0.043 \\
\hline HOMA-IR & 0.34 & 0.033 & - & NS \\
\hline Matsuda & -0.34 & 0.034 & - & NS \\
\hline SBP & 0.32 & 0.044 & - & NS \\
\hline
\end{tabular}

$A U C$ area under the curve, HOMA-IR homoeostatic model assessment of insulin resistance, Matsuda Matsuda insulin sensitivity index, SBP systolic blood pressure, $N S$ not significant

a $r$-Values are Spearman correlation coefficients. Variables with $p$ value $<0.05$ were considered to multivariate stepwise regression analysis

${ }^{\mathrm{b}}$ Only the variables that had a $p$ value $<0.05$ were considered in the final fitted model. Std $\beta$ is the standard beta coefficient

multivariate regression analysis; glucose AUC during OGTT (standard $\beta$ coefficient $=0.32, p<0.05$; model: $r^{2}=$ 0.27 ) remained the only significant predictor of FKBP5 gene expression in SAT (Table 2). See Supplementary Results for additional details on associations between FKBP5 gene expression and metabolic parameters.

\section{Expression of the FKBP5 gene is associated with genes regulating lipolysis, glucose uptake and adipogenesis in SAT}

SAT gene expression data from the Cohort 1 subjects revealed that FKBP5 gene expression levels were associated with genes regulated by the GR. There were positive associations with $G R(r=0.45, p<0.01)$ and $C N R I$ $(r=0.50, \quad p<0.01)$ and inverse associations with 
Table 3 Associations between FKBP5 gene expression and various metabolic genes in subcutaneous adipose tissue from Cohort 1

\begin{tabular}{|c|c|c|c|c|c|c|c|c|c|c|}
\hline & \multicolumn{2}{|c|}{$\begin{array}{l}\text { All subjects }(n= \\
40)\end{array}$} & \multicolumn{2}{|c|}{$\mathrm{ND}(n=20)$} & \multicolumn{2}{|c|}{$\mathrm{T} 2 \mathrm{D}(n=20)$} & \multicolumn{2}{|c|}{ Male $(n=20)$} & \multicolumn{2}{|c|}{$\begin{array}{l}\text { Female }(n= \\
20)\end{array}$} \\
\hline & $r$ & $p$ & $r$ & $p$ & $r$ & $p$ & $r$ & $p$ & $r$ & $p$ \\
\hline \multicolumn{11}{|c|}{ GR-regulated genes } \\
\hline$H S D 11 B 1$ & 0.07 & 0.686 & 0.19 & 0.420 & 0.06 & 0.803 & -0.11 & 0.642 & 0.27 & 0.247 \\
\hline$G R$ & 0.45 & 0.004 & 0.66 & 0.002 & 0.12 & 0.620 & 0.62 & 0.003 & 0.25 & 0.290 \\
\hline HSP90AA1 & 0.20 & 0.206 & 0.34 & 0.144 & 0.15 & 0.537 & 0.18 & 0.452 & 0.31 & 0.177 \\
\hline HSP90AB1 & 0.12 & 0.481 & 0.19 & 0.431 & 0.06 & 0.818 & 0.08 & 0.726 & 0.12 & 0.617 \\
\hline HSP9OB1 & $-\mathbf{0 . 3 9}$ & 0.013 & -0.41 & 0.076 & -0.21 & 0.368 & -0.36 & 0.118 & -0.44 & 0.053 \\
\hline CNRI & 0.50 & 0.001 & 0.54 & 0.015 & 0.43 & 0.059 & 0.40 & 0.078 & 0.64 & 0.002 \\
\hline GILZ & 0.27 & 0.089 & 0.26 & 0.268 & 0.35 & 0.129 & 0.03 & 0.892 & 0.16 & 0.515 \\
\hline TIMP4 & -0.43 & 0.006 & -0.60 & 0.005 & -0.35 & 0.126 & -0.32 & 0.165 & -0.56 & 0.010 \\
\hline \multicolumn{11}{|c|}{ Genes of inflammatory cytokines } \\
\hline$T N F$ & -0.02 & 0.895 & 0.01 & 0.964 & -0.15 & 0.526 & -0.07 & 0.781 & 0.11 & 0.636 \\
\hline$I F N G$ & 0.05 & 0.758 & -0.08 & 0.746 & 0.29 & 0.231 & 0.31 & 0.198 & -0.33 & 0.161 \\
\hline \multicolumn{11}{|c|}{ Genes of adipokines } \\
\hline$A D I P O Q$ & 0.06 & 0.730 & 0.36 & 0.117 & -0.12 & 0.602 & 0.15 & 0.525 & 0.39 & 0.091 \\
\hline$L E P$ & -0.28 & 0.084 & -0.25 & 0.286 & -0.30 & 0.206 & -0.20 & 0.399 & 0.01 & 0.983 \\
\hline \multicolumn{11}{|c|}{ Lipid metabolism genes } \\
\hline PDE3B & 0.60 & 0.000 & 0.62 & 0.004 & 0.49 & $\mathbf{0 . 0 3 0}$ & 0.64 & 0.002 & 0.65 & 0.002 \\
\hline$A T G L$ & -0.50 & 0.001 & $-\mathbf{0 . 5 3}$ & 0.016 & -0.47 & 0.035 & -0.40 & 0.083 & -0.56 & 0.011 \\
\hline$M G L L$ & -0.51 & 0.001 & -0.56 & 0.011 & -0.50 & 0.025 & -0.31 & 0.177 & -0.40 & 0.077 \\
\hline LIPE & -0.28 & 0.082 & -0.09 & 0.696 & -0.42 & 0.064 & -0.23 & 0.321 & -0.22 & 0.351 \\
\hline PLIN1 & -0.26 & 0.107 & -0.41 & 0.072 & -0.27 & 0.338 & -0.13 & 0.586 & -0.48 & 0.031 \\
\hline PLIN2 & 0.05 & 0.772 & 0.23 & 0.325 & 0.33 & 0.154 & -0.28 & 0.240 & 0.37 & 0.108 \\
\hline PLIN3 & -0.47 & 0.002 & 0.39 & 0.087 & -0.49 & 0.029 & -0.58 & 0.008 & -0.32 & 0.175 \\
\hline PLIN4 & -0.43 & 0.006 & -0.50 & 0.026 & -0.45 & 0.046 & -0.35 & 0.136 & -0.49 & 0.028 \\
\hline$L P L$ & -0.05 & 0.746 & 0.16 & 0.506 & -0.15 & 0.543 & 0.10 & 0.674 & 0.18 & 0.462 \\
\hline DGAT1 & -0.62 & 0.000 & -0.58 & 0.007 & -0.60 & 0.005 & -0.45 & 0.045 & -0.76 & 0.000 \\
\hline DGAT2 & -0.44 & 0.004 & $-\mathbf{0 . 5 3}$ & 0.015 & -0.38 & 0.096 & -0.10 & 0.690 & -0.50 & 0.025 \\
\hline \multicolumn{11}{|c|}{ Glucose metabolism genes } \\
\hline IRS1 & -0.19 & 0.235 & -0.05 & 0.849 & -0.28 & 0.236 & -0.10 & 0.681 & -0.08 & 0.738 \\
\hline GLUT4 & -0.30 & 0.061 & -0.43 & 0.061 & -0.30 & 0.194 & -0.10 & 0.664 & -0.51 & 0.022 \\
\hline$A K T$ & -0.28 & 0.081 & -0.33 & 0.153 & -0.23 & 0.321 & -0.14 & 0.555 & -0.30 & 0.205 \\
\hline$T B C 1 D 4$ & 0.50 & 0.001 & -0.03 & 0.890 & 0.01 & 0.982 & -0.03 & 0.904 & 00 & 1.000 \\
\hline \multicolumn{11}{|c|}{ Genes in mitochondrial energy metabolism } \\
\hline CPTIA & -0.01 & 0.951 & -0.32 & 0.166 & 0.17 & 0.475 & -0.12 & 0.614 & 0.07 & 0.761 \\
\hline$C P T 1 B$ & -0.54 & 0.000 & -0.60 & 0.005 & -0.22 & 0.344 & -0.62 & 0.004 & -0.72 & 0.000 \\
\hline \multicolumn{11}{|c|}{ Adipogenic genes } \\
\hline$P P A R G$ & -0.43 & 0.005 & -0.44 & 0.051 & -0.43 & 0.056 & -0.23 & 0.330 & -0.47 & 0.037 \\
\hline CEBPA & $-\mathbf{0 . 5 0}$ & 0.001 & -0.73 & 0.000 & -0.36 & 0.121 & -0.34 & 0.147 & -0.73 & 0.000 \\
\hline
\end{tabular}

Bold values indicate statistical significance $(p<0.05)$

A complete list of gene names can be found in Supplementary Table 3

$N D$ non-diabetic
HSP90B1 $(r=-0.39, p<0.05)$ and TIMP4 $(r=-0.43, p$ $<0.01$ ) (Table 3).

Moreover, FKBP5 gene expression in SAT negatively correlated with expression levels of genes corresponding to key proteins involved in the lipolytic machinery. These included ATGL ( $r=-0.50)$, MGLL $(r=-0.51)$, PLIN3 $(r$ $=-0.47)$ and PLIN4 $(r=-0.43)(p<0.01$ for all $)$ In 
contrast, FKBP5 gene expression levels positively correlated with $P D E 3 B(r=0.60, p<0.001)$ (Table 3$)$.

FKBP5 gene expression was also found to negatively correlate with the lipogenic genes DGAT1 $(r=-0.62, p<$ $0.001)$ and DGAT2 $(r=-0.44, p<0.01)$ and the adipogenic genes $P P A R G$ and CEBPA $(r=-0.43,-0.50$, respectively; $p<0.01$ for both) (Table 3 ).

In relation to genes involved in glucose metabolism, $F K B P 5$ gene expression was found to positively correlate with the gene expression levels of TBC1D4 $(r=0.50, p<$ $0.01)$. There were also tendencies toward negative correlations between gene expression levels of FKBP5 with GLUT4 $(r=-0.30, p=0.061)$ and Akt $(r=-0.28, p=$ 0.081). However, FKBP5 gene expression levels did not correlate with basal or insulin-stimulated glucose uptake (Supplementary Table 1, Supplementary Figure 1).

\section{FKBP51 expression levels during differentiation of preadipocytes into adipocytes ex vivo}

Preadipocytes that differentiated into adipocytes in media with $0.1 \mu \mathrm{M}$ cortisol for 14 days had about 2-fold higher gene expression levels of FKBP5 compared to preadipocytes that differentiated in media with no cortisol during the same timeframe ( $p<0.05$, Fig. 2a).

At the protein level, cortisol treatment was shown to elicit a dose-response in FKBP51 expression. On day 7, preadipocytes differentiated with $0.1 \mu \mathrm{M}$ cortisol showed $46 \%$ higher FKBP51 expression levels than those differentiated with $0.01 \mu \mathrm{M}$ cortisol $(p<0.05$, Fig. $2 b)$. On day 14 , preadipocytes differentiated with $0.1 \mu \mathrm{M}$ cortisol showed $15 \%(p<0.01)$ and $61 \%(p<0.05)$ higher FKBP51 expression levels than those differentiated with $0.01 \mu \mathrm{M}$ and no cortisol, respectively (Fig. 2b).

Moreover, preadipocytes differentiated in the presence of 0.01 and $0.1 \mu \mathrm{M}$ cortisol showed a reduction tendency in FKBP51 protein expression levels from day 7 to 14 of differentiation of $38 \%(p=0.059)$ and $51 \%(p=0.052)$, respectively (Fig. 2b).

Varying concentrations of cortisol $(0,0.01$ and $0.1 \mu \mathrm{M})$ did not affect the differentiation rate of preadipocytes into adipocytes at day 7 or day 14 (Fig. 2c, Supplementary Figure 2).

Addition of dexamethasone for $24 \mathrm{~h}$ on day 16 of differentiation, increased FKBP51 gene and protein expression levels by 54 -fold ( $p=0.083$, not shown) and 20 -fold ( $p<$ 0.05 , Fig. 3a), respectively.

Moreover, $24 \mathrm{~h}$ treatment with dexamethasone reduced the basal glucose uptake rate by $27 \%(p<0.05)$ and showed a tendency to reduce the insulin-stimulated glucose uptake rate by $29 \%$ in ex vivo differentiated adipocytes (Fig. 3b).
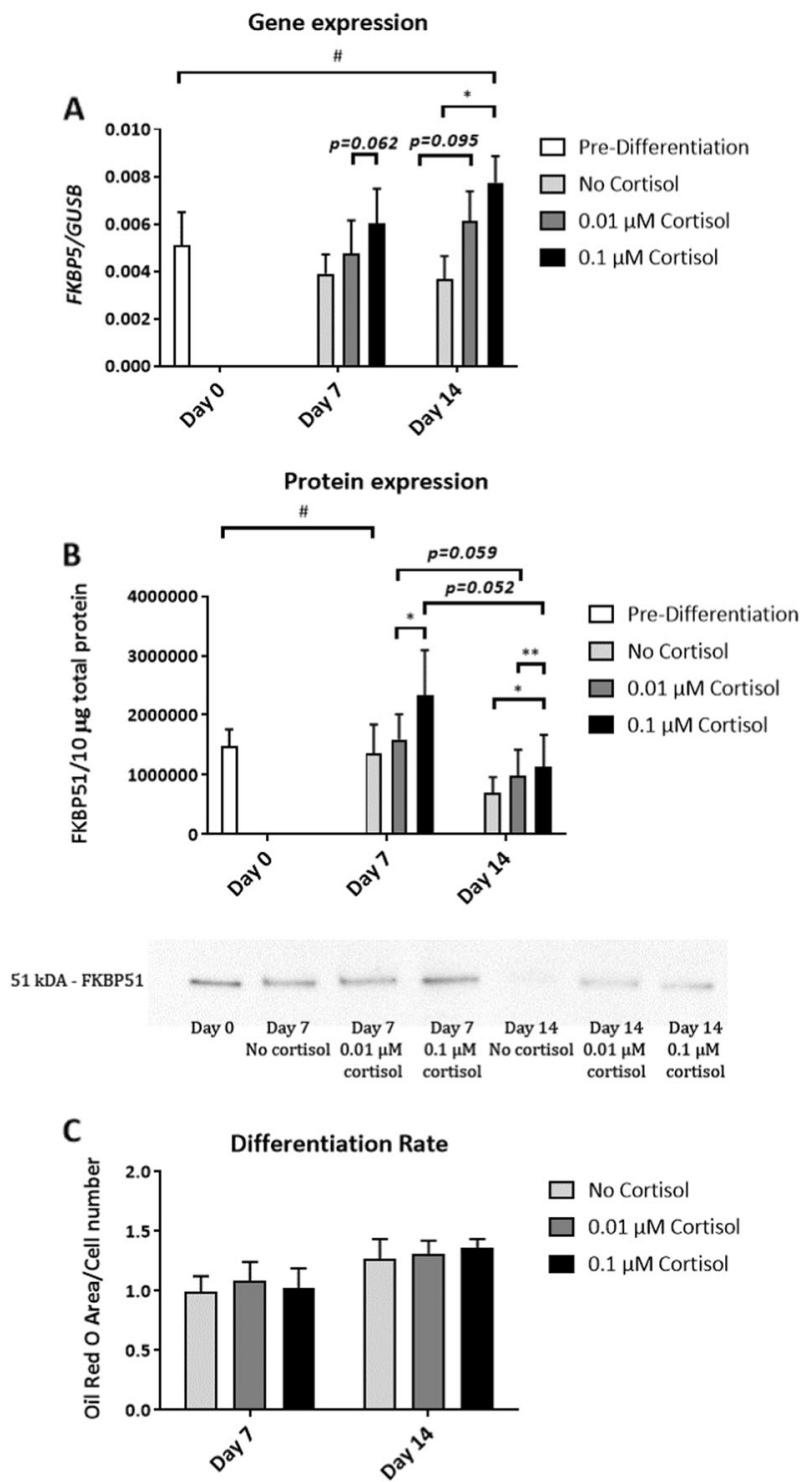

Fig. 2 FKBP5 expression during human preadipocyte differentiation into adipocyte. FKBP51 gene $\mathbf{a}$ and protein $\mathbf{b}$ expression levels in human preadipocytes before starting differentiation (pre-differentiation) and at days 7 and 14 after inducing differentiation into adipocytes without or with cortisol $(0.01$ and $0.1 \mu \mathrm{M})$ in the differentiation media $(n=5)$. Differentiation rate at days 7 and 14 of differentiation $(n=3)$, measured by image quantification of adipocyte lipids stained with Oil Red $\mathrm{O}$, and normalised by cell number $\mathbf{c} .{ }^{\#} p<0.05$, between different days; $* p<0.05, * * p<0.01$ between different treatments. Data were $\log (x+1)$ transformed

\section{SAFit1 can prevent dexamethasone-induced impairment of glucose uptake in isolated primary adipocytes}

Incubation of SAT for $24 \mathrm{~h}$ with dexamethasone reduced basal, 25 and $1000 \mu \mathrm{U} / \mathrm{ml}$ insulin-stimulated glucose uptake by $42 \%, 37 \%$ and $32 \%$, respectively $(p<0.001$ for all) in isolated primary adipocytes (Fig. 4a). Overall, coincubation with SAFit1 showed a dose-dependent trend to 


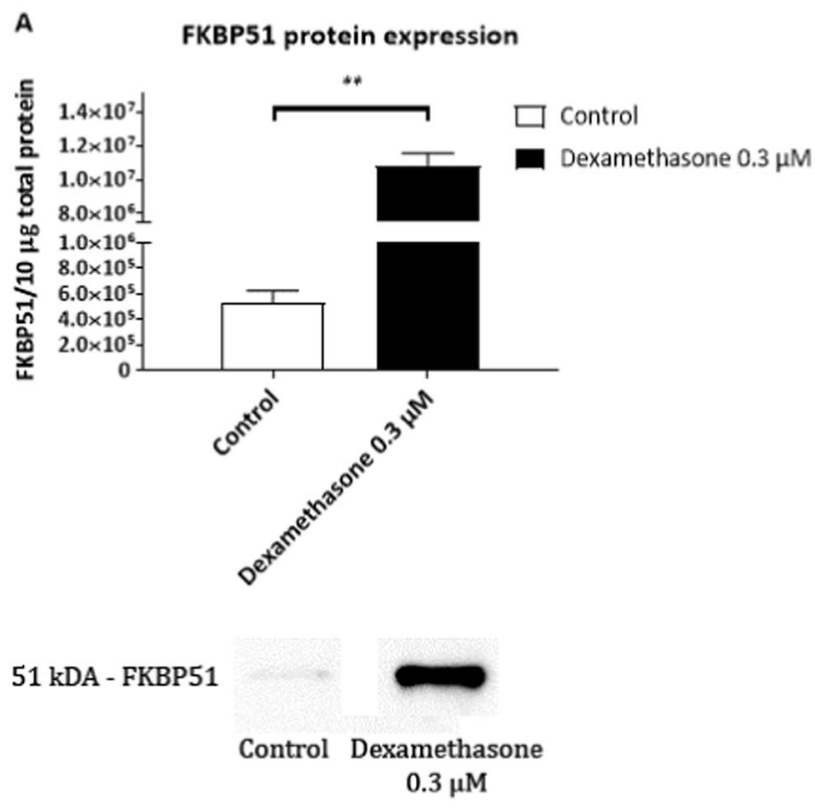

Fig. 3 FKBP51 protein expression levels were 20-fold elevated in preadipocytes differentiated into adipocytes ex vivo following $24 \mathrm{~h}$ incubation with dexamethasone $(0.3 \mu \mathrm{M})(n=4) \mathbf{a}$. Incubation for $24 \mathrm{~h}$

prevent impairment of basal and insulin-stimulated glucose uptake (Fig. 4a).

When dividing the individuals by the efficacy of dexamethasone treatment to inhibit glucose uptake, the responders (50th percentile and above) displayed a dosedependent rescue by SAFit1 to at least partly normalise glucose uptake (Fig. 4b, Supplementary Table 4). See Supplementary Results for additional details on SAFit1 effects on adipocyte glucose uptake.

\section{Effects of SAFit1 treatment on expression levels of genes regulated by GR}

As expected, treatment of SAT for $24 \mathrm{~h}$ with dexamethasone upregulated several genes known to be regulated by the GR-complex, including FKBP5 (14-fold, $p<$ 0.01), CNR1, GILZ, LPL (230-, 5- and 1.26-fold, respectively; $p<0.001)$ and PPARG (1.22-fold, $p<0.05)$ (data not shown). Dexamethasone was also shown to downregulate the genes GR, IL-6 (1.4- and 4-fold, respectively; $p<$ 0.001), HSP90AA1 (1.4-fold, $p<0.01$ ) and IRS-1 (1.2-fold, $p<0.05$ ) (data not shown). Co-incubation with SAFit1 had no effect on these gene expression levels.

\section{Discussion}

In this study, we expanded on our previous findings [12] by using a larger and more diverse cohort that includes non-

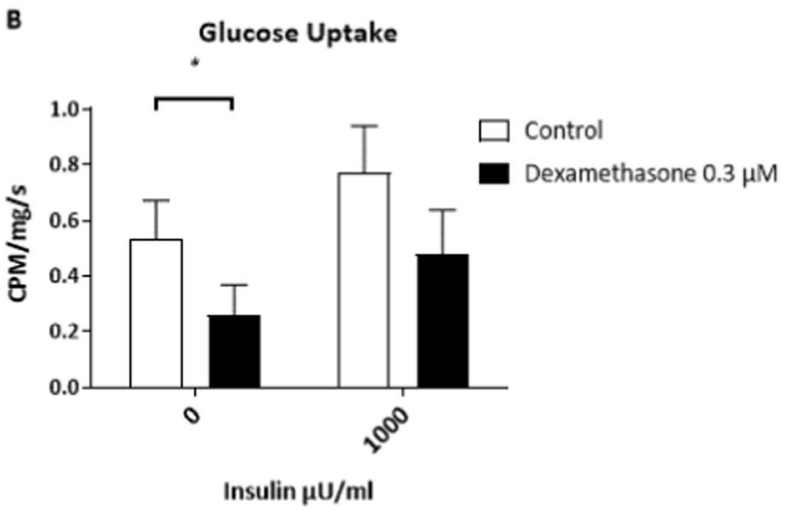

with dexamethasone reduced basal glucose uptake in preadipocytes differentiated into adipocytes ex vivo by $51 \%(n=4) \mathbf{b}$. Data were $\log$ $(x+1)$ transformed

diabetic and T2D subjects that were very well matched for sex, age and BMI. We show that FKBP5 gene expression has strong links to insulin resistance, and that it displays a tendency of elevation in T2D subjects. We show that this association is mostly predicted by glucose AUC during OGTT data, with the strongest contributions to the association being observed in non-diabetic obese subjects. This may link into previous findings of the rs1360780 polymorphism of the FKBP5 gene being associated to attenuated weight reduction following bariatric surgery of obese patients [19]. We previously reported that in $24 \mathrm{~h}$ incubated SAT, FKBP5 gene expression correlates positively to fasting insulin [12]. In the present study fresh SAT did not show correlation. These differences may be due to the different treatments of the SAT-incubated SAT vs fresh SAT and the different biopsy procedures - surgical vs needle biopsies [38] used in previous [12] and in this study, respectively. Moreover, we found that FKBP5 gene expression in SAT negatively correlated with genes corresponding to proteins involved in lipolysis. However, only in obese subjects was FKBP5 gene expression levels found to be associated with the lipolytic rate of isolated adipocytes. The contribution of SVF, which contains several cell types, including blood cells, endothelial cells, adipose precursor cells, macrophages and fibroblasts, could potentially explain the absence of a correlation between FKBP5 gene expression in SAT and lipolysis in isolated adipocytes.

FKBP5 gene expression levels did not correlate with BMI, waist circumference or waist-hip ratio (WHR). This 

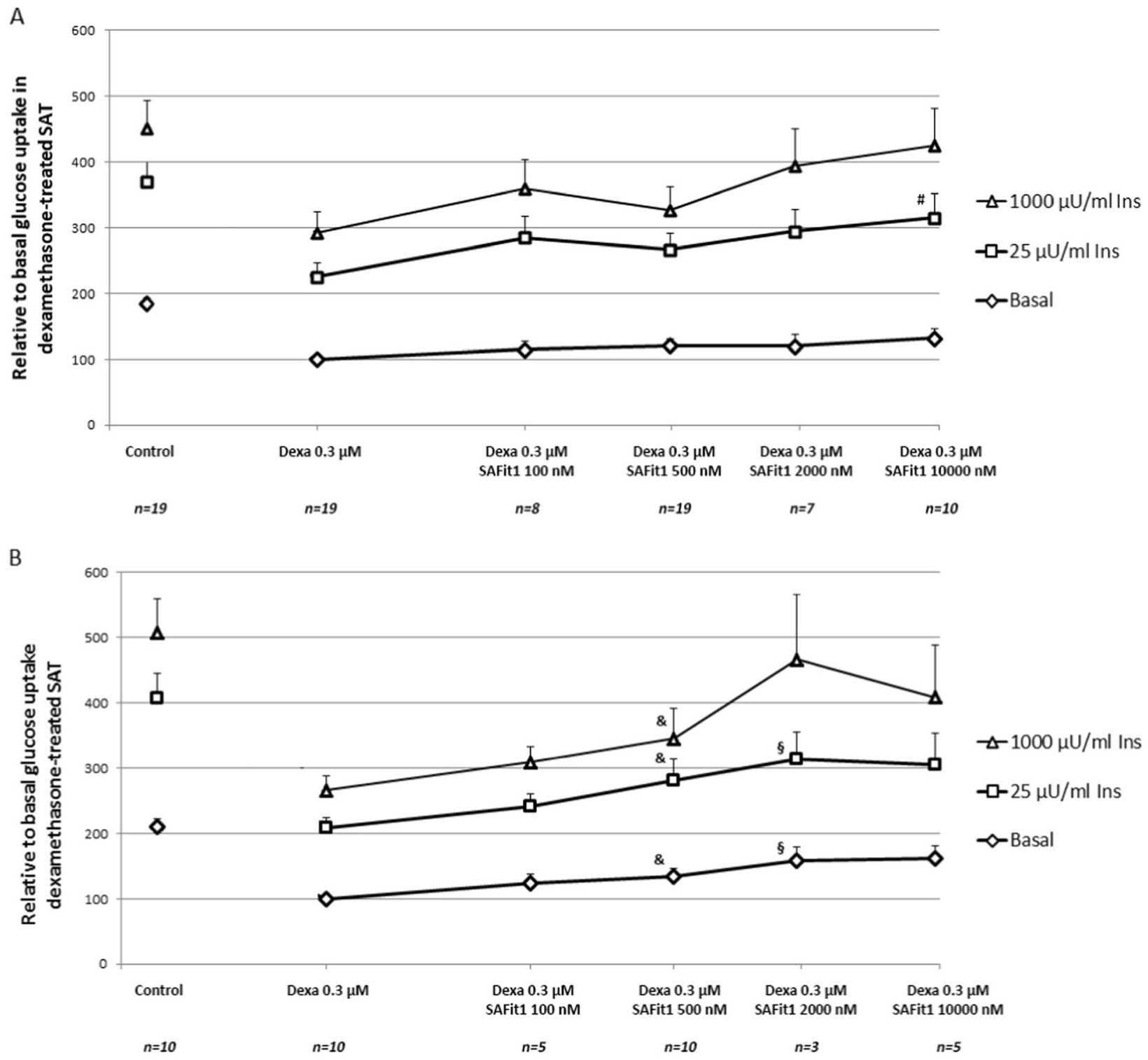

Fig. 4 SAFit1 dose-response curve for adipocyte glucose uptake obtained from adipose tissue treated for $24 \mathrm{~h}$ with dexamethasone $(0.3 \mu \mathrm{M})$ and with different concentrations of SAFit1 $(100-10,000 \mathrm{nM})(n=7-19)$ a and SAFit1 dose-response curve for adipocyte glucose uptake with higher percent inhibitory effect of dexamethasone on glucose uptake (50th percentile and above, $n=$ 3-10), compared with control (no dexamethasone treatment), after

$24 \mathrm{~h}$ of incubation b. For reference, the basal glucose uptake in all subjects was $38.0 \mathrm{femtoliter} / \mathrm{cell} / \mathrm{s}$ (control). Values are percentage relative to basal dexamethasone. Dexa Dexamethasone, SAT subcutaneous adipose tissue. ${ }^{\circledR} p<0.05$, Dexa + SAFit1 $(500 \mathrm{nM})$ treated vs Dexa treated; ${ }^{\S} p<0.05$, Dexa + SAFit1 $(2000 \mathrm{nM})$ treated vs Dexa treated; ${ }^{\#} p<0.05$, Dexa + SAFit1 $(10,000 \mathrm{nM})$ treated vs Dexa treated

suggests that other obesity-associated mechanisms or states could be at play in a potential role of FKBP51 in lipid metabolism.

We found that FKBP5 gene expression correlates negatively with two of the principal genes regulating adipogenesis, i.e. PPARG and CEBPA [39], suggesting that FKBP51 might be involved in adipocyte differentiation. Furthermore, recent studies have demonstrated that FKBP51 regulates PPARG activity, and therefore adipogenesis via the GR through an Akt-p38 kinase pathway
[24]. It has also been demonstrated that the knockdown or knockout of the FKBP5 gene in 3T3-L1 cells [24] or mouse embryonic fibroblasts [23, 24], respectively, has a strong anti-adipogenic impact in cells. It is, however, difficult to pinpoint the exact causality of $F K B P 5$ expression, or lack thereof, on adipogenesis. Our results seem to suggest that although FKBP51 levels tend to positively correlate with cortisol concentrations; these varying FKBP51 levels do not seem to affect the differentiation rate in human preadipocytes. However, with these experiments we do not 
exclude a role of FKBP51 on adipocyte differentiation, since even in cells differentiated in absence of cortisol there were basal levels of FKBP51 protein that could be sufficient to induce differentiation of preadipocytes into adipocytes. Further studies with complete knock-out of FKBP51 are warranted to explore the role of FKBP51 in human adipocyte differentiation. Furthermore, our data indicate that FKBP51 protein expression levels progressively decrease during differentiation. A reduction in FKBP51 levels during differentiation implies that FKBP51 may have a greater role in the earlier stages of adipogenesis rather than in later stages. This is in accordance with the reported roles of CEPBA and PPARG in the early stages of the differentiation process [40].

In line with previous findings [12], we showed that the synthetic glucocorticoid dexamethasone elevated FKBP51 gene and protein expression levels in human adipose tissue. We also found that dexamethasone had a similar effect on FKBP51 expression levels in adipocytes differentiated ex vivo. In addition, the effects of dexamethasone on inhibiting glucose uptake in primary adipocytes isolated from incubated SAT were also observed in adipocytes differentiated ex vivo. Addition of SAFit1 together with dexamethasone was shown to prevent the dexamethasoneinduced impairment of glucose uptake of SAT incubated with dexamethasone alone. We found that this prevention by SAFit1 was dependent on the efficacy of dexamethasone treatment to inhibit glucose uptake. In short-term incubation conditions with SAFit1 (data not shown), no recovery of dexamethasone's inhibitory effects on glucose uptake were observed. This suggests that the mechanism is unlikely to be mediated by the rapid phosphorylation events in the insulin signalling cascade. Furthermore, the effects of SAFit1 were similar in basal (no insulin) and insulinstimulated conditions and there was no apparent shift in the insulin concentration-response curve, thus suggesting no effect on insulin signalling.

To better understand how FKBP51 may be involved in mediating glucose uptake, we examined the effects of dexamethasone/SAFit1 incubation on gene expression levels of genes downstream of the GR in SAT. We found that dexamethasone had significant effects on several GRregulated genes, including GR expression itself and FKBP5. However, co-incubation of dexamethasone and SAFit1 had no additional effects. This may imply that SAFit1 does not interfere with the FKBP51-GR interaction. Furthermore, it may suggest that the mechanism by which SAFit1 prevents dexamethasone's effects on glucose uptake, are not mediated via genetic downstream pathways.

An involvement of FKBP51 in Akt-pathways and its direct interaction with $\mathrm{Akt} / \mathrm{PKB}$ has previously been demonstrated [20, 24, 41-43]. The FKBP51 protein consists of the two FKBP-type (FK) domains, FK1, FK2 and a tetratricopeptide repeat (TPR) domain [44]. The FK1 and FK2 domains interact with Akt whereas the TPR domain interacts with elements of the GR, where it regulates glucocorticoid affinity and downstream gene regulation of the GR complex [44]. Deletion of residues corresponding to the two Akt-associated domains has been shown to abolish Akt interaction [20]. A SAFit1 analogue was shown reorganise the Akt2-AS160 complex in muscle tissue of mice [45], but ligands binding to the FK506/SAFit1-binding pocket in the FK1 domain of FKBP51 did not affect the FKBP51-Akt interaction [46].

A recent study found that FKBP51-knockout mice had improved insulin-mediated glucose uptake in skeletal muscle compared to wild type mice [45]. In line with our findings, the study found that FKBP51 regulates Akt-AS160 phosphorylation. In contrast to our findings, glucose metabolism did not differ in white adipose tissue of the FKBP51-knockout mice compared to wild type mice. Based on these findings, it would be of interest to further investigate a possible interplay of FKBP51-Akt-AS160 and to evaluate FKBP51 inhibition in human skeletal muscle.

This study has several limitations. First it is limited by its exploratory nature, and the associations between FKBP5 levels and the expression levels of other genes do not demonstrate causality. Future studies should closer examine FKBP51 in relation to the other gene products highlighted here. Second, an examination of FKBP51 in SAT alone may not convey much of a systemic role of FKBP51. Therefore, it would be of interest to dissect FKBP51's role in other metabolically active tissues; in particular skeletal muscle tissue and liver which quantitatively account for much of insulin-mediated glucose metabolism. Third, it is an ex vivo study, therefore the impact of the needle biopsy on the adipose tissue gene expression and adipocyte metabolism is unknown. Fourth, the study is further limited by the unknown exact mechanism of action of SAFit1. We cannot completely rule out effects of SAFit1 on phosphorylation in the insulin signalling cascade. In this paper, we have further underscored the role of FKBP51 in metabolism and, specifically, its link to insulin resistance and T2D in SAT. Previously published SNP data of the FKBP5 gene region have showed several SNPs being associated to T2D and related phenotypes [12]. In addition, the gene variant rs1360780 was recently shown to be associated with WHR [47, 48]. These findings give additional support to an association between FKBP51 and T2D-related phenotypes.

Moreover, we demonstrate a potential direct role of FKBP51 in the glucose turnover machinery. This was demonstrated by the use of the FKBP51-specific inhibitor SAFit1 to prevent dexamethasone-induced insulin resistance in human adipose tissue. 
Having established a glucose uptake assay in adipocytes differentiated ex vivo, it would be of interest to completely knock out the expression of the FKBP5 gene in human preadipocytes. This would help clarify the involvement of FKBP51 in adipogenesis and its role in the glucose uptake machinery that is impaired by dexamethasone in SAT. Regulation of FKBP51 by different levels of cortisol during differentiation does not affect the differentiation rate. An FKBP5 knockout model may clarify why. The purported protein-protein interaction between FKBP51, Akt and possibly AS160 should also be further investigated.

In conclusion, we have found that FKBP5 expression in human subcutaneous adipose tissue is associated with T2D traits and markers of insulin resistance. It can also partly mediate effects of glucocorticoids to impair glucose utilisation, and this may partly be prevented by a selective FKBP51 inhibitor. Furthermore, FKBP5 gene expression is associated with genes involved in lipid metabolism and adipogenesis, thus further supporting the involvement of FKBP51 in metabolic regulation.

Acknowledgements We gratefully acknowledge the valuable technical, administrative, analytical contributions and expert advice from coworkers at Uppsala University Hospital. We are also grateful to coworkers at AstraZeneca R\&D for excellent scientific support. Valuable scientific advice from Mathias Schmidt and Alexander Häusl, Max Planck Institute of Psychiatry, Munich is gratefully acknowledged.

Funding This work was supported by research grants from the Swedish Diabetes Foundation, the Exodiab (Excellence Of Diabetes Research in Sweden), the Ernfors Foundation, the Uppsala University Hospital ALF grants, the Swedish Society for Medical Research, AstraZeneca R\&D, the Portuguese Foundation for Science and Technology (SFRH/BD/41044/2007 and PTDC/SAU-OSM/104124/ 2008), the M4 Award 2015 (BIO-1601-0003 to F.H.), the BMBF/ ERA-IB grant 'TACRODRUGS' (031B0269B) and the Swedish Research Council.

\section{Compliance with ethical standards}

Conflict of interest S.S. is employed by AstraZeneca R\&D. The other authors declare that they have no conflict of interest.

Ethical approval All procedures performed in studies involving human participants were in accordance with the ethical standards of the institutional and/or national research committee and with the 1964 Helsinki declaration and its later amendments or comparable ethical standards.

Informed consent Informed consent was obtained from all individual participants included in the study.

Open Access This article is distributed under the terms of the Creative Commons Attribution 4.0 International License (http://crea tivecommons.org/licenses/by/4.0/), which permits use, duplication, adaptation, distribution, and reproduction in any medium or format, as long as you give appropriate credit to the original author(s) and the source, provide a link to the Creative Commons license, and indicate if changes were made.

\section{References}

1. WHO, Obesity and Overweight (World Health Organization, 2015).

2. B.B. Kahn, J.S. Flier, Obesity and insulin resistance. J. Clin. Invest. 106(4), 473-481 (2000). https://doi.org/10.1172/JCI10842

3. S.E. Kahn, R.L. Hull, K.M. Utzschneider, Mechanisms linking obesity to insulin resistance and type 2 diabetes. Nature $\mathbf{4 4 4}$ (7121), 840-846 (2006). https://doi.org/10.1038/nature05482

4. M.W. Schwartz, S.E. Kahn, Insulin resistance and obesity. Nature 402(6764), 860-861 (1999). https://doi.org/10.1038/47209

5. V.T. Samuel, G.I. Shulman, The pathogenesis of insulin resistance: integrating signaling pathways and substrate flux. J. Clin. Invest. 126(1), 12-22 (2016). https://doi.org/10.1172/JCI77812

6. S.E. Kahn, The relative contributions of insulin resistance and beta-cell dysfunction to the pathophysiology of type 2 diabetes. Diabetologia 46(1), 3-19 (2003). https://doi.org/10.1007/s00125002-1009-0

7. M.E. Cerf, Beta cell dysfunction and insulin resistance. Front. Endocrinol. (Lausanne) 4, 37 (2013). https://doi.org/10.3389/ fendo.2013.00037

8. T. Rhen, J.A. Cidlowski, Antiinflammatory action of glucocorticoids—new mechanisms for old drugs. N. Engl. J. Med. 353(16), 1711-1723 (2005). https://doi.org/10.1056/NEJMra050541

9. H.E. Rugstad, Antiinflammatory and immunoregulatory effects of glucocorticoids: mode of action. Scand. J. Rheumatol. Suppl. 76, 257-264 (1988)

10. E.B. Geer, J. Islam, C. Buettner, Mechanisms of glucocorticoidinduced insulin resistance: focus on adipose tissue function and lipid metabolism. Endocrinol. Metab. Clin. North Am. 43(1), 75-102 (2014). https://doi.org/10.1016/j.ecl.2013.10.005

11. D.R. Repaske, Medication-induced diabetes mellitus. Pediatr. Diabetes 17(6), 392-397 (2016). https://doi.org/10.1111/pedi. 12406

12. M.J. Pereira, J. Palming, M.K. Svensson, M. Rizell, J. Dalenback, M. Hammar, T. Fall, C.O. Sidibeh, P.A. Svensson, J.W. Eriksson, FKBP5 expression in human adipose tissue increases following dexamethasone exposure and is associated with insulin resistance. Metabolism 63(9), 1198-1208 (2014). https://doi.org/10.1016/j. metabol.2014.05.015

13. A. Menke, T. Klengel, J. Rubel, T. Bruckl, H. Pfister, S. Lucae, M. Uhr, F. Holsboer, E.B. Binder, Genetic variation in FKBP5 associated with the extent of stress hormone dysregulation in major depression. Genes Brain Behav. 12(3), 289-296 (2013). https://doi.org/10.1111/gbb.12026

14. Q. Wang, R.C. Shelton, Y. Dwivedi, Interaction between earlylife stress and FKBP5 gene variants in major depressive disorder and post-traumatic stress disorder: a systematic review and metaanalysis. J. Affect. Disord. 225, 422-428 (2017). https://doi.org/ 10.1016/j.jad.2017.08.066

15. J.C. O'Leary 3rd, B. Zhang, J. Koren 3rd, L. Blair, C.A. Dickey, The role of FKBP5 in mood disorders: action of FKBP5 on steroid hormone receptors leads to questions about its evolutionary importance. CNS Neurol. Disord. Drug Targets 12(8), 1157-1162 (2013)

16. J.P. Herman, J.M. McKlveen, S. Ghosal, B. Kopp, A. Wulsin, R. Makinson, J. Scheimann, B. Myers, Regulation of the hypothalamic-pituitary-adrenocortical stress response. Compr. Physiol. 6(2), 603-621 (2016). https://doi.org/10.1002/cphy. c150015

17. H. Henneicke, S.J. Gasparini, T.C. Brennan-Speranza, H. Zhou, M.J. Seibel, Glucocorticoids and bone: local effects and systemic implications. Trends Endocrinol. Metab. 25(4), 197-211 (2014). https://doi.org/10.1016/j.tem.2013.12.006 
18. A.S. Zannas, G. Balsevich, N.C. Gassen, The emerging role of FKBP5 in the regulation of metabolism and body weight. Surg. Obes. Relat. Dis. 12(8), 1560-1561 (2016). https://doi.org/10. 1016/j.soard.2016.05.016

19. I.B. Hartmann, G.R. Fries, J. Bucker, E. Scotton, L. von Diemen, M. Kauer-Sant'Anna, The FKBP5 polymorphism rs1360780 is associated with lower weight loss after bariatric surgery: 26 months of follow-up. Surg. Obes. Relat. Dis. 12(8), 1554-1560 (2016). https://doi.org/10.1016/j.soard.2016.04.016

20. H. Pei, L. Li, B.L. Fridley, G.D. Jenkins, K.R. Kalari, W. Lingle, G. Petersen, Z. Lou, L. Wang, FKBP51 affects cancer cell response to chemotherapy by negatively regulating Akt. Cancer Cell 16(3), 259-266 (2009). https://doi.org/10.1016/j.ccr.2009.07. 016

21. G. Balsevich, A. Uribe, K.V. Wagner, J. Hartmann, S. Santarelli, C. Labermaier, M.V. Schmidt, Interplay between diet-induced obesity and chronic stress in mice: potential role of FKBP51. J. Endocrinol. 222(1), 15-26 (2014). https://doi.org/10.1530/JOE14-0129

22. L.A. Stechschulte, B. Qiu, M. Warrier, T.D. Hinds Jr., M. Zhang, H. Gu, Y. Xu, S.S. Khuder, L. Russo, S.M. Najjar, B. LeckaCzernik, W. Yong, E.R. Sanchez, FKBP51 null mice are resistant to diet-induced obesity and the PPARgamma agonist rosiglitazone. Endocrinology 157(10), 3888-3900 (2016). https://doi.org/ 10.1210/en.2015-1996

23. L. Zhang, B. Qiu, T. Wang, J. Wang, M. Liu, Y. Xu, C. Wang, R. Deng, K. Williams, Z. Yang, T. Liang, W. Yong, Loss of FKBP5 impedes adipocyte differentiation under both normoxia and hypoxic stress. Biochem. Biophys. Res. Commun. 485(4), 761-767 (2017). https://doi.org/10.1016/j.bbrc.2017.02.126

24. L.A. Stechschulte, T.D. Hinds Jr., S.S. Khuder, W. Shou, S.M. Najjar, E.R. Sanchez, FKBP51 controls cellular adipogenesis through p38 kinase-mediated phosphorylation of GRalpha and PPARgamma. Mol. Endocrinol. 28(8), 1265-1275 (2014). https:// doi.org/10.1210/me.2014-1022

25. A.I. Su, T. Wiltshire, S. Batalov, H. Lapp, K.A. Ching, D. Block, J. Zhang, R. Soden, M. Hayakawa, G. Kreiman, M.P. Cooke, J.R. Walker, J.B. Hogenesch, A gene atlas of the mouse and human protein-encoding transcriptomes. Proc. Natl. Acad. Sci. U.S.A. 101(16), 6062-6067 (2004). https://doi.org/10.1073/pnas. 0400782101

26. S. Vandevyver, L. Dejager, C. Libert, On the trail of the glucocorticoid receptor: into the nucleus and back. Traffic 13(3), 364-374 (2012). https://doi.org/10.1111/j.1600-0854.2011.01288. $\mathrm{x}$

27. E.B. Binder, The role of FKBP5, a co-chaperone of the glucocorticoid receptor in the pathogenesis and therapy of affective and anxiety disorders. Psychoneuroendocrinology 34(Suppl. 1), S186-S195 (2009). https://doi.org/10.1016/j.psyneuen.2009.05. 021

28. D. Sinclair, S.G. Fillman, M.J. Webster, C.S. Weickert, Dysregulation of glucocorticoid receptor co-factors FKBP5, BAG1 and PTGES3 in prefrontal cortex in psychotic illness. Sci. Rep. 3, 3539 (2013). https://doi.org/10.1038/srep03539

29. A.G. Erlejman, S.A. De Leo, G.I. Mazaira, A.M. Molinari, M.F. Camisay, V. Fontana, M.B. Cox, G. Piwien-Pilipuk, M.D. Galigniana, NF-kappaB transcriptional activity is modulated by FK506-binding proteins FKBP51 and FKBP52: a role for peptidyl-prolyl isomerase activity. J. Biol. Chem. 289(38), 26263-26276 (2014). https://doi.org/10.1074/jbc.M114.582882

30. M.J. Pereira, S. Skrtic, P. Katsogiannos, N. Abrahamsson, C.O. Sidibeh, S. Dahgam, M. Månsson, U. Risérus, J. Kullberg, J.W. Eriksson, Impaired adipose tissue lipid storage, but not altered lipolysis, contributes to elevated levels of NEFA in type 2 diabetes. Degree of hyperglycemia and adiposity are important.
Metabolism. (2016). https://dx.doi.org/10.1016/j. metabol.2016.09.008.

31. S. Gaali, A. Kirschner, S. Cuboni, J. Hartmann, C. Kozany, G. Balsevich, C. Namendorf, P. Fernandez-Vizarra, C. Sippel, A.S. Zannas, R. Draenert, E.B. Binder, O.F. Almeida, G. Ruhter, M. Uhr, M.V. Schmidt, C. Touma, A. Bracher, F. Hausch, Selective inhibitors of the FK506-binding protein 51 by induced fit. Nat. Chem. Biol. 11(1), 33-37 (2015). https://doi.org/10.1038/ nchembio. 1699

32. M.T. Nakada, J.M. Stadel, K.S. Poksay, S.T. Crooke, Glucocorticoid regulation of beta-adrenergic receptors in 3T3-L1 preadipocytes. Mol. Pharmacol. 31(4), 377-384 (1987)

33. I.E. Widmer, J.J. Puder, C. Konig, H. Pargger, H.R. Zerkowski, J. Girard, B. Muller, Cortisol response in relation to the severity of stress and illness. J. Clin. Endocrinol. Metab. 90(8), 4579-4586 (2005). https://doi.org/10.1210/jc.2005-0354

34. M.J. Lee, S.K. Fried, Optimal protocol for the differentiation and metabolic analysis of human adipose stromal cells. Methods Enzymol. 538, 49-65 (2014). https://doi.org/10.1016/B978-0-12800280-3.00004-9

35. F.S. Newell, H. Su, H. Tornqvist, J.P. Whitehead, J.B. Prins, L.J. Hutley, Characterization of the transcriptional and functional effects of fibroblast growth factor-1 on human preadipocyte differentiation. FASEB J. 20(14), 2615-2617 (2006). https://doi.org/ 10.1096/fj.05-5710fje

36. S. Ngo, J.B. Barry, J.C. Nisbet, J.B. Prins, J.P. Whitehead, Reduced phosphorylation of AS160 contributes to glucocorticoidmediated inhibition of glucose uptake in human and murine adipocytes. Mol. Cell. Endocrinol. 302(1), 33-40 (2009). https://doi. org/10.1016/j.mce.2008.10.020

37. J.P. Whitehead, J.C. Molero, S. Clark, S. Martin, G. Meneilly, D. E. James, The role of $\mathrm{Ca} 2+$ in insulin-stimulated glucose transport in 3T3-L1 cells. J. Biol. Chem. 276(30), 27816-27824 (2001). https://doi.org/10.1074/jbc.M011590200

38. D.M. Mutch, J. Tordjman, V. Pelloux, B. Hanczar, C. Henegar, C. Poitou, N. Veyrie, J.D. Zucker, K. Clement, Needle and surgical biopsy techniques differentially affect adipose tissue gene expression profiles. Am. J. Clin. Nutr. 89(1), 51-57 (2009). https://doi.org/10.3945/ajcn.2008.26802

39. E.D. Rosen, C.H. Hsu, X. Wang, S. Sakai, M.W. Freeman, F.J. Gonzalez, B.M. Spiegelman, C/EBPalpha induces adipogenesis through PPARgamma: a unified pathway. Genes Dev. 16(1), 22-26 (2002). https://doi.org/10.1101/gad.948702

40. T. Hishida, M. Nishizuka, S. Osada, M. Imagawa, The role of C/ EBPdelta in the early stages of adipogenesis. Biochimie 91(5), 654-657 (2009). https://doi.org/10.1016/j.biochi.2009.02.002

41. J. Yu, B. Qin, F. Wu, S. Qin, S. Nowsheen, S. Shan, J. Zayas, H. Pei, Z. Lou, L. Wang, Regulation of serine-threonine kinase Akt activation by NAD+-dependent deacetylase SIRT7. Cell Rep. 18 (5), 1229-1240 (2017). https://doi.org/10.1016/j.celrep.2017.01. 009

42. D.J. Mulholland, L.M. Tran, Y. Li, H. Cai, A. Morim, S. Wang, S. Plaisier, I.P. Garraway, J. Huang, T.G. Graeber, H. Wu, Cell autonomous role of PTEN in regulating castration-resistant prostate cancer growth. Cancer Cell 19(6), 792-804 (2011). https:// doi.org/10.1016/j.ccr.2011.05.006

43. J. Brognard, E. Sierecki, T. Gao, A.C. Newton, PHLPP and a second isoform, PHLPP2, differentially attenuate the amplitude of Akt signaling by regulating distinct Akt isoforms. Mol. Cell 25(6), 917-931 (2007). https://doi.org/10.1016/j.molcel.2007.02.017

44. L. Li, Z. Lou, L. Wang, The role of FKBP5 in cancer aetiology and chemoresistance. Br. J. Cancer 104(1), 19-23 (2011). https:// doi.org/10.1038/sj.bjc.6606014

45. G. Balsevich, A.S. Hausl, C.W. Meyer, S. Karamihalev, X. Feng, M.L. Pohlmann, C. Dournes, A. Uribe-Marino, S. Santarelli, C. Labermaier, K. Hafner, T. Mao, M. Breitsamer, M. 
Theodoropoulou, C. Namendorf, M. Uhr, M. Paez-Pereda, G. Winter, F. Hausch, A. Chen, M.H. Tschop, T. Rein, N.C. Gassen, M.V. Schmidt, Stress-responsive FKBP51 regulates AKT2AS160 signaling and metabolic function. Nat. Commun. 8(1), 1725 (2017). https://doi.org/10.1038/s41467-017-01783-y

46. A.K. Fabian, A. Marz, S. Neimanis, R.M. Biondi, C. Kozany, F. Hausch, InterAKTions with FKBPs-mutational and pharmacological exploration. PLoS One 8(2), e57508 (2013). https://doi. org/10.1371/journal.pone.0057508

47. D. Shungin, T.W. Winkler, D.C. Croteau-Chonka, T. Ferreira, A. E. Locke, R. Magi, R.J. Strawbridge, T.H. Pers, K. Fischer, A.E. Justice, T. Workalemahu, J.M.W. Wu, M.L. Buchkovich, N.L. Heard-Costa, T.S. Roman, A.W. Drong, C. Song, S. Gustafsson, F.R. Day, T. Esko, T. Fall, Z. Kutalik, J. Luan, J.C. Randall, A. Scherag, S. Vedantam, A.R. Wood, J. Chen, R. Fehrmann, J. Karjalainen, B. Kahali, C.T. Liu, E.M. Schmidt, D. Absher, N. Amin, D. Anderson, M. Beekman, J.L. Bragg-Gresham, S. Buyske, A. Demirkan, G.B. Ehret, M.F. Feitosa, A. Goel, A.U. Jackson, T. Johnson, M.E. Kleber, K. Kristiansson, M. Mangino, I.M. Leach, C. Medina-Gomez, C.D. Palmer, D. Pasko, S. Pechlivanis, M.J. Peters, I. Prokopenko, A. Stancakova, Y.J. Sung, T. Tanaka, A. Teumer, J.V. Van Vliet-Ostaptchouk, L. Yengo, W. Zhang, E. Albrecht, J. Arnlov, G.M. Arscott, S. Bandinelli, A. Barrett, C. Bellis, A.J. Bennett, C. Berne, M. Bluher, S. Bohringer, F. Bonnet, Y. Bottcher, M. Bruinenberg, D. B. Carba, I.H. Caspersen, R. Clarke, E.W. Daw, J. Deelen, E. Deelman, G. Delgado, A.S. Doney, N. Eklund, M.R. Erdos, K. Estrada, E. Eury, N. Friedrich, M.E. Garcia, V. Giedraitis, B. Gigante, A.S. Go, A. Golay, H. Grallert, T.B. Grammer, J. Grassler, J. Grewal, C.J. Groves, T. Haller, G. Hallmans, C.A. Hartman, M. Hassinen, C. Hayward, K. Heikkila, K.H. Herzig, Q. Helmer, H.L. Hillege, O. Holmen, S.C. Hunt, A. Isaacs, T. Ittermann, A.L. James, I. Johansson, T. Juliusdottir, I.P. Kalafati, L. Kinnunen, W. Koenig, I.K. Kooner, W. Kratzer, C. Lamina, K. Leander, N.R. Lee, P. Lichtner, L. Lind, J. Lindstrom, S. Lobbens, M. Lorentzon, F. Mach, P.K. Magnusson, A. Mahajan, W.L. McArdle, C. Menni, S. Merger, E. Mihailov, L. Milani, R. Mills, A. Moayyeri, K.L. Monda, S.P. Mooijaart, T.W. Muhleisen, A. Mulas, G. Muller, M. Muller-Nurasyid, R. Nagaraja, M.A. Nalls, N. Narisu, N. Glorioso, I.M. Nolte, M. Olden, N.W. Rayner, F. Renstrom, J.S. Ried, N.R. Robertson, L.M. Rose, S. Sanna, H. Scharnagl, S. Scholtens, B. Sennblad, T. Seufferlein, C.M. Sitlani, A.V. Smith, K. Stirrups, H.M. Stringham, J. Sundstrom, M.A. Swertz, A.J. Swift, A.C. Syvanen, B.O. Tayo, B. Thorand, G. Thorleifsson, A. Tomaschitz, C. Troffa, F.V. van Oort, N. Verweij, J.M. Vonk, L.L. Waite, R. Wennauer, T. Wilsgaard, M.K. Wojczynski, A. Wong, Q. Zhang, J.H. Zhao, E.P. Brennan, M. Choi, P. Eriksson, L. Folkersen, A. Franco-Cereceda, A.G. Gharavi, A.K. Hedman, M.F. Hivert, J. Huang, S. Kanoni, F. Karpe, S. Keildson, K. Kiryluk, L. Liang, R.P. Lifton, B. Ma, A.J. McKnight, R. McPherson, A. Metspalu, J.L. Min, M.F. Moffatt, G.W. Montgomery, J.M. Murabito, G. Nicholson, D.R. Nyholt, C. Olsson, J.R. Perry, E. Reinmaa, R.M. Salem, N. Sandholm, E.E.
Schadt, R.A. Scott, L. Stolk, E.E. Vallejo, H.J. Westra, K.T. Zondervan; Consortium, A.D., Consortium, C.A.D., Consortium, C.K., Consortium, G., Consortium, G., Glgc, Icbp, International Endogene, C., LifeLines Cohort, S., Investigators, M., T.C. Mu, P. Consortium, C. ReproGen, P. Amouyel, D. Arveiler, S.J. Bakker, J. Beilby, R.N. Bergman, J. Blangero, M.J. Brown, M. Burnier, H. Campbell, A. Chakravarti, P.S. Chines, S. Claudi-Boehm, F.S. Collins, D.C. Crawford, J. Danesh, U. de Faire, E.J. de Geus, M. Dorr, R. Erbel, J.G. Eriksson, M. Farrall, E. Ferrannini, J. Ferrieres, N.G. Forouhi, T. Forrester, O.H. Franco, R.T. Gansevoort, C. Gieger, V. Gudnason, C.A. Haiman, T.B. Harris, A.T. Hattersley, M. Heliovaara, A.A. Hicks, A.D. Hingorani, W. Hoffmann, A. Hofman, G. Homuth, S.E. Humphries, E. Hypponen, T. Illig, M.R. Jarvelin, B. Johansen, P. Jousilahti, A.M. Jula, J. Kaprio, F. Kee, S.M. Keinanen-Kiukaanniemi, J.S. Kooner, C. Kooperberg, P. Kovacs, A.T. Kraja, M. Kumari, K. Kuulasmaa, J. Kuusisto, T.A. Lakka, C. Langenberg, L. Le Marchand, T. Lehtimaki, V. Lyssenko, S. Mannisto, A. Marette, T.C. Matise, C.A. McKenzie, B. McKnight, A.W. Musk, S. Mohlenkamp, A.D. Morris, M. Nelis, C. Ohlsson, A.J. Oldehinkel, K.K. Ong, L.J. Palmer, B.W. Penninx, A. Peters, P.P. Pramstaller, O.T. Raitakari, T. Rankinen, D.C. Rao, T.K. Rice, P.M. Ridker, M.D. Ritchie, I. Rudan, V. Salomaa, N.J. Samani, J. Saramies, M.A. Sarzynski, P. E. Schwarz, A.R. Shuldiner, J.A. Staessen, V. Steinthorsdottir, R. P. Stolk, K. Strauch, A. Tonjes, A. Tremblay, E. Tremoli, M.C. Vohl, U. Volker, P. Vollenweider, J.F. Wilson, J.C. Witteman, L. S. Adair, M. Bochud, B.O. Boehm, S.R. Bornstein, C. Bouchard, S. Cauchi, M.J. Caulfield, J.C. Chambers, D.I. Chasman, R.S. Cooper, G. Dedoussis, L. Ferrucci, P. Froguel, H.J. Grabe, A. Hamsten, J. Hui, K. Hveem, K.H. Jockel, M. Kivimaki, D. Kuh, M. Laakso, Y. Liu, W. Marz, P.B. Munroe, I. Njolstad, B.A. Oostra, C.N. Palmer, N.L. Pedersen, M. Perola, L. Perusse, U. Peters, C. Power, T. Quertermous, R. Rauramaa, F. Rivadeneira, T.E. Saaristo, D. Saleheen, J. Sinisalo, P.E. Slagboom, H. Snieder, T.D. Spector, K. Stefansson, M. Stumvoll, J. Tuomilehto, A.G. Uitterlinden, M. Uusitupa, P. van der Harst, G. Veronesi, M. Walker, N.J. Wareham, H. Watkins, H.E. Wichmann, G.R. Abecasis, T.L. Assimes, S.I. Berndt, M. Boehnke, I.B. Borecki, P. Deloukas, L. Franke, T.M. Frayling, L.C. Groop, D.J. Hunter, R. C. Kaplan, J.R. O'Connell, L. Qi, D. Schlessinger, D.P. Strachan, U. Thorsteinsdottir, C.M. van Duijn, C.J. Willer, P.M. Visscher, J. Yang, J.N. Hirschhorn, M.C. Zillikens, M.I. McCarthy, E.K. Speliotes, K.E. North, C.S. Fox, I. Barroso, P.W. Franks, E. Ingelsson, I.M. Heid, R.J. Loos, L.A. Cupples, A.P. Morris, C.M. Lindgren, K.L. Mohlke, New genetic loci link adipose and insulin biology to body fat distribution. Nature 518(7538), 187-196 (2015). https://doi.org/10.1038/nature14132

48. J.R. Staley, J. Blackshaw, M.A. Kamat, S. Ellis, P. Surendran, B. B. Sun, D.S. Paul, D. Freitag, S. Burgess, J. Danesh, R. Young, A. S. Butterworth, PhenoScanner: a database of human genotypephenotype associations. Bioinformatics 32(20), 3207-3209 (2016). https://doi.org/10.1093/bioinformatics/btw373 